essentially an assessment of the cultural and psychological distance between this country and the normative western models. Meanwhile, China basing on the concept of a powerful cultural state has developed its own alternative to the theories of J. Nye. This article proves the impossibility of a model of soft power suitable for all, because the practices of its application are determined by specific goals and objectives, which can differ very significantly from one state to another. In the light of this approach, the author compares the American and Chinese soft power strategies in terms of their effectiveness and dynamics. In particular, there is a decrease in the attractiveness of the United States and the strengthening of the "Soft" influence of China. The author notes that in the modern world a situation of a parallel dominance of states using soft power of various types is possible.

Keywords: political influence, soft power, country's image, international environment, political strategy

ГОМЕЛАУРИ Ангелина Сергеевна - аспирант факультета политологии Санкт-Петербургского государственного университета (199034, Россия, г. Санкт-Петербург, Университетская наб., 7-9; gomelauri@yandex.ru)

\title{
АРКТИЧЕСКИЕ ТРАНСФОРМАЦИИ: РОССИЯ ДЕКЛАРИРУЕТ «ЖЕСТКУЮ СИЛУ»
}

\begin{abstract}
Аннотация. Сквозь призму концепций «мягкой» и «жесткой» силы, предложенных американским политологом Дж. Наем в начале 1990-х гг., в статье анализируется декларируемый российским государством курс, избранный для защиты арктических интересов, которые в настоящее время приобрели большую значимость, т.к. Арктика является регионом, который хранит ценные ресурсы, обладание которыми становится предметом международных дискуссий, тем более что границы арктических владений все еще подвижны. Соответственно, актуальным становится вопрос, какими методами могут быть достигнуты арктические цели России. В сложившейся ситуации государство предпочло сделать ставку на «жесткую силу», что обусловлено напряженной ситуацией, сложившейся на международной арене.
\end{abstract}

Ключевые слова: «мягкая сила», «жесткая сила», Российская Федерация, Арктика

$\mathrm{A}$ рктика - регион, имеющий стратегически важные запасы ресурсов, была обречена стать центром пересечения геополитических интересов ряда государств, имеющих достаточные основания, чтобы вступить в борьбу за обладание арктическими богатствами. На данный момент границы Арктики не закреплены единым определением.

С 1920-х гг. Арктика разделена на 5 территориальных секторов между Россией, Канадой, США, Норвегией и Данией. Стоит, однако, отметить, что их границы периодически претерпевают изменения. Так, ратифицировав в 1997 г. Конвенцию по морскому праву, принятую в 1982 г., Российская Федерация пошла на компромисс с рядом зарубежных государств, потеряв при этом существенную часть акватории [Смирнов 2016: 11]. Указанная конвенция не решила все спорные вопросы вокруг арктических территорий. В 2010 г. Россия и Норвегия подписали договор о разграничении морских пространств, ставший результатом переговоров, длившихся в течение нескольких десятилетий: по условиям договора спорные территории в Баренцевом море и Северном Ледовитом океане были разделены на две равные части ${ }^{1}$, что привело к уступке Россией части акватории, принадлежавшей, согласно постановле-

1 Договор между Российской Федерацией и Королевством Норвегия о разграничении морских пространств и сотрудничестве в Баренцевом море и Северном Ледовитом океане. Доступ: http://www.kremlin.ru/supplement/707 (проверено 10.03.2021). 
нию Президиума ЦИК СССР от 15 апреля 1926 г., Советскому Союзуํ․ В 2014 г. Комиссия ООН удовлетворила заявку России на расширение внешних границ континентального шельфа за счет участка в Охотском море [Смирнов 2016: 22]. На текущий момент на ряд территорий, включая хребет Ломоносова, заявляют притязания сразу несколько арктических государств ${ }^{2}$. Решение вопросов о принадлежности зон Арктики, выстраивание стратегий по добыче ресурсов и развитию территорий, равно как и иные проблемы арктических пространств, занимает годы и требует кропотливой дипломатической работы.

Целью данного исследования стало выявление российского потенциала «мягкой силы» в сфере решения арктических вопросов.

Исследование опирается на метод case study, использованы методики неформализованного анализа официальных документов и источников научной информации.

Начало комплексному освоению Арктического региона было положено в XVII в.: вслед за служилыми людьми прибывали на Крайний Север торговцы и поселенцы, заинтересованные промысловыми перспективами. За ними, уже в XVIII в., пришли и исследователи, обеспечившие проведение первых геологоразведочных работ, а также систематическое картографирование новых территорий. Официальное заявление на международном уровне о принадлежности арктических территорий последовало в 1916 г., когда Российская империя объявила о включении в ее состав всех земель, «расположенных к северу от азиатского побережья» ${ }^{3}$. Указанное заявление было подтверждено в 1924 г. меморандумом Правительства $\mathrm{CCCP}^{4}$. Основополагающим документом стало постановление Президиума ЦИК СССР от 15 апреля 1926 г. «Об объявлении территорией Союза ССР земель и островов, расположенных в Северном Ледовитом океане», в котором были определены северные границы страны ${ }^{5}$.

Стоит отметить, что большевики, пришедшие к власти по итогам революции, стремились всемерно содействовать делу развития Арктики, утверждая свое влияние на арктической территории, несмотря на масштабные проблемы внутри страны. Так, например, в 1920 г. была организована Северная научнопромысловая экспедиция, занимавшаяся освоением Северного морского пути, реорганизованная к 1925 г. в Институт по изучению Севера (сейчас Арктический и Антарктический научно-исследовательский институт). С 1926 г. начинается активная колонизация окраинных территорий: на о. Врангеля и арх. Земля Франца-Иосифа организуются зимовки, строятся полярные станции. Завоевание Арктики становится одной из провозглашенных на государственном уровне целей. Одним из актов демонстрации советских достижений

1 Постановление Президиума ЦИК СССР от 15.04.1926 «Об объявлении территорией Союза ССР земель и островов, расположенных в Северном Ледовитом океане». Доступ: https://www.consultant.ru/cons/cgi/online.cgi?req=doc\&base=ESU $\& n=8470 \# 09072480928568902$ (проверено 10.03.2021).

2 Burdina A. Several countries lay claim to disputed Lomonosov Ridge. Доступ: https://arctic. ru/analitic/20181115/804847.html (проверено 12.03.2021).

3 Федосеев Л. Российские владения в Арктике. История и проблемы международноправового статуса. Доступ: https://tass.ru/info/6312329 (проверено 19.03.2021).

4 Меморандум Правительства СССР Правительству США от 4 ноября 1924 года № 297. Доступ: http://history-library.com/index.php?id1=3\&category=istoriya-rossii\&author=gromikoaa\&book=196424\&page=236 (проверено 19.03.2021).

5 Постановление Президиума ЦИК СССР от 15.04 .1926 «Об объявлении территорией Союза ССР земель и островов, расположенных в Северном Ледовитом океане». Доступ: https://www.consultant.ru/cons/cgi/online.cgi? req=doc\&base=ESU $\& \mathrm{n}=8470 \# 09072480928568902$ (проверено 10.03.2021). 
в покорении арктических территорий стал беспосадочный перелет экипажа В.П. Чкалова из Москвы в Ванкувер через Северный полюс в 1937 г.

Освоение Арктики являлось не только вопросом международного престижа. На рубеже 1930-х гг. начинается добыча нефти в промышленных масштабах (с Чибьюского месторождения). В местах добычи полезных ископаемых строятся города Норильск и Воркута, для удобства перевозок возникают порты НарьянМар, Игарка, Диксон и пр. В тех же 1930-х гг. создается Главсевморпуть - централизованное управление, отвечающее за обеспечение активности северного морского маршрута.

В период Второй мировой войны арктические территории стали зоной боевых действий, что замедляет научно-исследовательские и геологоразведочные работы. Однако с окончанием войны изыскательские работы продолжатся: к 1980-м гг. будут обнаружены крупные месторождения нефти и газа, в т.ч. и на арктическом шельфе (в частности, месторождение «Приразломное»). Кроме того, возобновлется и презентация силы советской стороной: в 1977 г. состоялся поход ледокола «Арктика» к географической точке Северного полюса с поднятием флага Советского Союза, приуроченный к 60-летию Октябрьской революции.

Рассматривая многолетний опыт масштабного и планомерного освоения Арктики на протяжении XX столетия, можно сделать вывод, что работы велись в двух направлениях: непосредственно в прикладном (научные, разведочные, строительные и прочие комплексы работы) и в презентативном, позволяющем продемонстрировать достижения международному сообществу и оказать «привлекательное» влияние. Таким образом, речь идет о продуцировании «мягкой силы». Стоит заметить, что в 1990-е гг., кризисный для страны период, деятельность и в одном и в другом направлении была прервана.

Постепенное восстановление активности началось в нулевых годах, что не только нашло свое отражение в эффективных действиях по развитию арктических земель (с особым вниманием к геологоразведочным работам, разработке месторождений, научно-исследовательской деятельности, экологической поддержке региона и пр.), но и было задекларировано на официальном уровне. В 2008 г. был принят документ, определивший ключевые цели в сфере развития арктических территорий, - Основы государственной политики Российской Федерации в Арктике на период до 2020 года и дальнейшую перспективу, который не только охватил социально-экономические, экологические, научно-технологические области, но и поднял вопрос о международном сотрудничестве ${ }^{1}$. Среди приоритетных задач отмечалось выстраивание отношений с приарктическими государствами «с учетом национальных интересов Российской Федерации» ${ }^{2}$. Реализация указанной задачи требовала активизации деятельности России в региональных институтах, являющихся площадками арктического диалога (Арктический совет, Совет Баренцева/ Евроарктического региона), мобилизации сотрудничества с приграничными государствами, а также организации участия государственных институтов и общественных организаций в международной деятельности по проблемам Арктики. В 2013 г. была разработана Стратегия развития Арктической зоны Российской Федерации и обеспечения национальной безопасности на период до 2020 года, расширяющая положения, декларируемые в Основах... 2008, в т.ч. и в части развития международного сотрудничества с приарктическими

1 Основы государственной политики Российской Федерации в Арктике на период до 2020 года и дальнейшую перспективу. Доступ: http://static.government.ru/media/files/A4qP6 brLNJ175I40U0K46x4SsKRHGfUO.pdf (проверено 22.03.2021).

2 Там же. 
государствами для укрепления добрососедских отношений, а также активизации взаимодействия в области культуры, экономики, научно-технического развития и пр. ${ }^{1}$ Координационные вопросы требовали решения, и в 2015 г. была создана Государственная комиссия по вопросам развития Арктики, к чьей компетенции была отнесена работа по обеспечению связи между федеральным центром и регионами, корректированию целей и задач арктической политики в условиях изменяющихся реалий, а также проверка результативности программ и проектов, реализуемых в Арктике ${ }^{2}$. Далее, в марте 2020 г. были утверждены Основы государственной политики Российской Федерации в Арктике на период до 2035 года, определяющие основные планы на развитие Арктической зоны, отметившие угрозы и вызовы. Документ уделил особое внимание вопросам национальной безопасности, а также укреплению «жесткой силы» посредством повышения боевых возможностей воинских формирований, развернутых в российской арктической зоне 3 . Причинами тому стали усиление иностранными государствами военного присутствия в арктической зоне, увеличение риска конфликтов в регионе, а также посягательства на суверенитет России в Арктике и дискредитация деятельности страны со стороны зарубежных государств и международных организаций ${ }^{4}$. Характерно, что упор на «жесткую силу» был продемонстрирован и в принятой в октябре 2020 г. Стратегии развития Арктической зоны Российской Федерации и обеспечения национальной безопасности на период до 2035 года, где определены основные вызовы и угрозы, в числе которых внешние проблемы - рост конфликтного потенциала и опасности из-за рубежа (попадание в Арктику высокотоксичных отходов, возбудителей инфекционных заболеваний, микроорганизмов, радиоактивных веществ) ${ }^{5}$. Между тем, несмотря на неблагоприятную атмосферу, обусловленную действиями зарубежных государств, Российская Федерация по-прежнему готова к установлению благожелательных партнерских отношений. Об этом свидетельствует заявление о важности развития связей с зарубежными странами в деле поддержки коренных народов, разработки образовательных программ, привлечения инвесторов и пр. 6 Соответственно, невозможно не отметить некоторую «мягкость» Стратегии по сравнению с Основами... 2020 в контексте международных отношений. Однако объявление о необходимости наращивания боевой силы в Арктике указывает на то, что с 2008 г. РФ существенно скорректировала свой взгляд на выстраивание международных отношений вокруг Арктического региона. Итак, не будет преувеличением сказать, что на государственном уровне наблюдается переход к явно декларируемой «жесткой силе». Подобные трансформации нельзя назвать неожиданными: с 2014 г., ставшего кризисным для России, ее взаимоотношения с рядом стран заметно ухудшились. Недовольство зарубежных государств возвращением в состав федерации полуострова Крым, выраженное в ряде существенных огра-

1 Стратегия развития Арктической зоны Российской Федерации и обеспечения национальной безопасности на период до 2020 года. Доступ: http://government.ru/info/18360/ (проверено 22.03.2021).

2 Государственная комиссия по вопросам развития Арктики. Доступ: https://arctic.gov.ru/ about-us-overall/ (проверено 23.03.2021).

3 Основы государственной политики Российской Федерации в Арктике на период до 2035 года. Доступ: https://www.garant.ru/products/ipo/prime/doc/73606526/ (проверено 23.03.2021).

4 Там же.

5 Стратегия развития Арктической зоны Российской Федерации и обеспечения национальной безопасности на период до 2035 года. Доступ: https:/www.garant.ru/products/ipo/ prime/doc/74710556/ (проверено 23.03.2021).

6 Там же. 
ничений, накладываемых на действия России в международном пространстве (введение различного рода санкций, ограничение доступа к площадкам для выстраивания международного диалога и пр.), повлекло необходимость выработки ответных мер на проявляемую агрессию, затронувших различные аспекты политики, в т.ч. и по арктическому вопросу.

Арктический регион требует неустанного внимания со стороны РФ и, соответственно, выстраивания грамотной политики по проблемам Арктики как с сопредельными приарктическими, так и с иными заинтересованными государствами и объединениями. На протяжении нескольких веков присутствие России в Арктике декларировалось по принципу присутствия де-факто, и только в XX в. этот вопрос был поставлен на правовые рельсы, что повлекло некоторые сложности в решении территориальных вопросов. Между тем территориальные претензии - не единственная проблема, требующая стратегизированного подхода. Ресурсный потенциал Арктики привлекает различные государства, что, соответственно, выдвигает на международный уровень как экономические вопросы, так и ряд сопутствующих им - вопросы безопасности, экологии и пр. Отстаивание интересов государства по указанным проблемам требует, в свою очередь, использования механизмов «мягкой силы», могущих сгладить существующее напряжение. Однако, анализируя декларируемые на уровне государства взгляды на арктическую политику, можно сделать вывод о достаточно заметном переходе от «мягкой» к «жесткой» силе, что обусловливается осложнением взаимоотношений между Россией и рядом европейских государств, а также США.

Итак, рассмотрение российского потенциала «мягкой силы» в арктической сфере продемонстрировало, что при наличии ресурсов для развития «мягкой» стратегии, обеспечивающей налаживание добрососедских отношений и создающей благоприятную атмосферу для продвижения государственных интересов, РФ в последнее время делает упор на «жесткую силу», что становится закономерным ответом на ряд «жестких» шагов, предпринятых зарубежными странами.

\section{Список литературы}

Смирнов А.И. 2016. Арктика: Сетевая дипломатия 2.0 в дискурсе глобальной безопасности. Архангельск: Изд-во САФУ. 157 с.

\section{ARCTIC TRANSFORMATIONS: RUSSIA DECLARES HARD POWER}

\footnotetext{
Abstract. The paper considers the issue of the Arctic policy produced by the Russian Federation. Through the prism of the concepts of soft and hard power, proposed by the American political scientist J. Nye in the early 1990s, the author analyzes the course declared by the state to protect the Arctic interests. Now such interests have acquired great importance: the Arctic is a region that stores valuable resources - natural gas reserves, oil fields, etc. The possession of these resources is becoming a subject of international debate, especially since the boundaries of the Arctic lands are still mobile (which, for example, is happening with the Lomonosov Ridge, which is the subject of a longstanding dispute between Russia, Canada, and Denmark). Therefore, the need to achieve the set goals in the development of the Arctic, while maintaining a delicate balance in the field of international relations, is extremely important for the state. The question of methods and mechanisms
} 
of achieving goals becomes relevant in the context of modern instability: the crisis in relations between Russia and many European states, as well as the United States, which erupted in 2014, still affects political processes associated with the state's activity in the foreign field. In this situation, the Russian Federation preferred to declare a hard power strategy in the Arctic Region, having officially formalized the transformation in international relations.

Keywords: soft power, hard power, Russian Federation, Arctic

\section{УДК 94}

СТАРКУС Пятрас - научный сотрудник Нижегородского государственного лингвистического университета им. Н.А. Добролюбова (603155, Россия, г. Нижний Новгород, ул. Минина, 31а); магистрант Нижегородского государственного педагогического университета им. К. Минина (603005, Россия, г. Нижний Новгород, ул. Ульянова, 1; starkuspi@mail.ru)

\section{ОЦЕНКА ДЕЙСТВИЙ СОВЕТСКОГО КОМАНДОВАНИЯ В ЛИТОВСКИХ УЧЕБНИКАХ ИСТОРИИ}

Аннотация. В данной статье рассматриваются два популярных литовских учебника по истории Новейшего времени. Предметом нашего исследования стала тема Второй мировой войны как одной из ключевых тем в формировании исторической памяти детей. В статье показано, какую роль, по мнению авторов учебников, сыграло советское руководство в победе над нацистской Германией.

Ключевые слова: историческая память, Великая Отечественная война, учебная литература Литвы, формирование исторической памяти, литовские учебники

$\mathrm{O}$ тношения между большинством стран Восточной Европы и Россией вряд ли можно назвать добрососедскими. В 1990-х и начале нулевых эти отношения можно было описать как стабильно отрицательные, но более предсказуемые. После волны экономических кризисов, начавшихся в 2008 г. и показавших экономическую несостоятельность многих стран бывшего СССР, взаимоотношения вошли в фазу взаимных обвинений ${ }^{1}$. Ключевой темой подобных споров часто является тема Второй мировой войны, хотя уже скоро не останется живых свидетелей тех событий. Учитывая тот факт, что с момента распада СССР прошло 30 лет, а русофобские настроения не теряют своей интенсивности, можно сделать вывод, что формирование исторической памяти происходило еще на школьной скамье и следует заглянуть в старые учебники по истории. Данная статья ставит своей целью исключительно ознакомление читателей с некоторыми установившимися положениями литовской учебной литературы.

Ключевой проблемой современной исторической науки является мифологизация исторических процессов. На слепой вере в «собственную» правду осно-

1 Marcinkevičius L. Lenkijos Senato vicepirmininkas: tikrasis pavojus Vakarams yra ne gèju paradai, o Rusijos tankai. - Lietuvos nacionalinis radijas ir televizija. 2021, kovo 27. Доступ: https:// www.lrt.lt/naujienos/lietuvoje/2/1374472/lenkijos-senato-vicepirmininkas-tikrasis-pavojusvakarams-yra-ne-geju-paradai-o-rusijos-tankai (проверено 28.03.2021); Запольская А. «Это были палачи» В Латвии снова почтили память легионеров СС. Как и зачем пособников нацистов превращают в героев? - Лента.ру. 17.03.2021. Доступ: https://lenta.ru/articles/ 2021/03/17/nazi_latvia/ (проверено 11.07.2021). 